\title{
Rafineri Projelerinde Planlamanın Önemi ve Başarılı Bir Planlama İçin Öneriler
}

\author{
Akın ER ${ }^{1 *}$, Rüveyda KÖMÜRLÜ²
}

Öz

Geçtiğimiz yüzyılın başından itibaren projelerin büyüklükleri hızla artarken yapıları da daha karmaşık bir hal almaya başlamıştır. Bu durum projelerin nasıl daha hızlı ve daha verimli yapılabileceği sorusunu beraberinde getirmiştir. Sonuçta proje yönetimi ve planlama kavramlarının önemi gün geçtikçe artmış, CPM ve PERT gibi planlama tekniklerinin geliştirilmesine sebep olmuştur. Günümüzdeki yatırım projelerinde planlama artık vazgeçilmez bir yönetim aracı haline gelmiştir. Yatırımcılar planladıkları yatırımlarının en hızlı şekilde hayata geçmesini beklemektedirler. Taahhüt tarafında ise rekabet artmış ve kaynaklarını en verimli kullanan firmalar bir adım öne geçmişlerdir. Büyük projelerin iş programları binlerce aktiviteyi içeren ve ancak bilgisayar desteği ile yönetilebilen bir noktaya gelmiştir. Bu makalede yatırım projelerinin en karmaşıklarından biri olan rafineri projelerinde planlama çalışmalarının içeriği üzerine genel bir yaklaşım sunulmak istenmiştir. Bugüne kadar edinilen tecrübelerle bu tip projelerin planlama çalışmalarının altyapısının kurulması ve takip detayları hakkında önerilerde bulunulmuştur.

Anahtar Kelimeler: Rafineri Projeleri, Planlama, İs Ayrışım Yapısı, İş Programı, Proje Yönetimi.

\section{Importance of Planning in Refinery Projects and Recommendations for Successful Planning}

\begin{abstract}
Since the beginning of last century, projects were not only rapidly enlarged but also organizations of them became more and more complex. Those changes brought into question of how projects could be realized faster and more productive. Consequently, importance of project management and planning has been raised day by day which resulted in development of planning technics such as CPM and PERT. Nowadays planning has become an inevitable management tool for investment projects. Investors are expecting to accomplish their projects as fast as possible. On the other hand, competition between contractors was increased, so contractors which use their resources more productively have competitive advantage. Time schedules of big projects have come to a point where they contain thousands of activities and can only be managed by means of computers. In this article, a general approach to the planning studies of refinery projects, which are recognized as one of the most complex type of construction, will be defined. Recommendations on preparation studies of the planning activities and monitoring details will be advised by the authors based on their experience at this kind of projects up to the present.
\end{abstract}

Keywords: Refinery Projects, Planning, Work Breakdown Structure, Schedule, Project Management.

\footnotetext{
${ }^{1}$ TÜPRAŞ Genel Müdürlüğü

${ }^{2}$ Kocaeli Üniversitesi Mimarlık ve Tasarım Fakültesi

* Illgili yazar/Corresponding author: akin.er@tupras.com.tr

Gönderim Tarihi: 05.11.2017
}

Kabul Tarihi: 08.12.2017 


\section{GíRiş}

Proje işin başında belirlenmiş olan bir hedefe, mevcut kaynakları kullanarak, öngörülen süre içerisinde ulaşabilmek için yapılması gerekenleri içeren bir çalışma olarak tanımlanabilir (Çimen, 1994, s.4). Bu tanımdan da anlaşılacağı üzere projelerde üç temel unsur söz konusudur; hedef (sonuç), bütçe (kaynaklar) ve zaman (Yalkı, 2009, s.3). Projelerin başarıları bu unsurların ne kadar verimli şekilde kullanıldığı ve belirlenen hedeflere ne seviyede ulaşıldığı değerlendirilerek ölçülür. Proje ekipleri projelerin başarılı olması için birçok süreci yönetirler. Bu süreçlerin birbiri ile uyumlu olarak yürütülmesi için harcanan çabanın tümü proje yönetimi olarak ifade edilebilir.

Başarılı bir proje ancak doğru bir yönetim anlayışı ile mümkün olur. Yapılan bir çalışmada proje yönetimlerinin yaşadıkları başarısızlıkların önemli nedenlerinden birinin, uygun proje yönetim tekniklerinin kullanılmaması olduğu belirtilmektedir (Munns, Bjeirmi, 1996, s.82). Diğer bir çalışmada ise başarılı bir planlama yapıldığında proje performansının önemli ölçüde iyileştiği anlatılmaktadır (Douglas, 2004, s. PS.07.1). Bu da bize planlamanın en önemli proje yönetim araçlarından biri olduğunu göstermektedir.

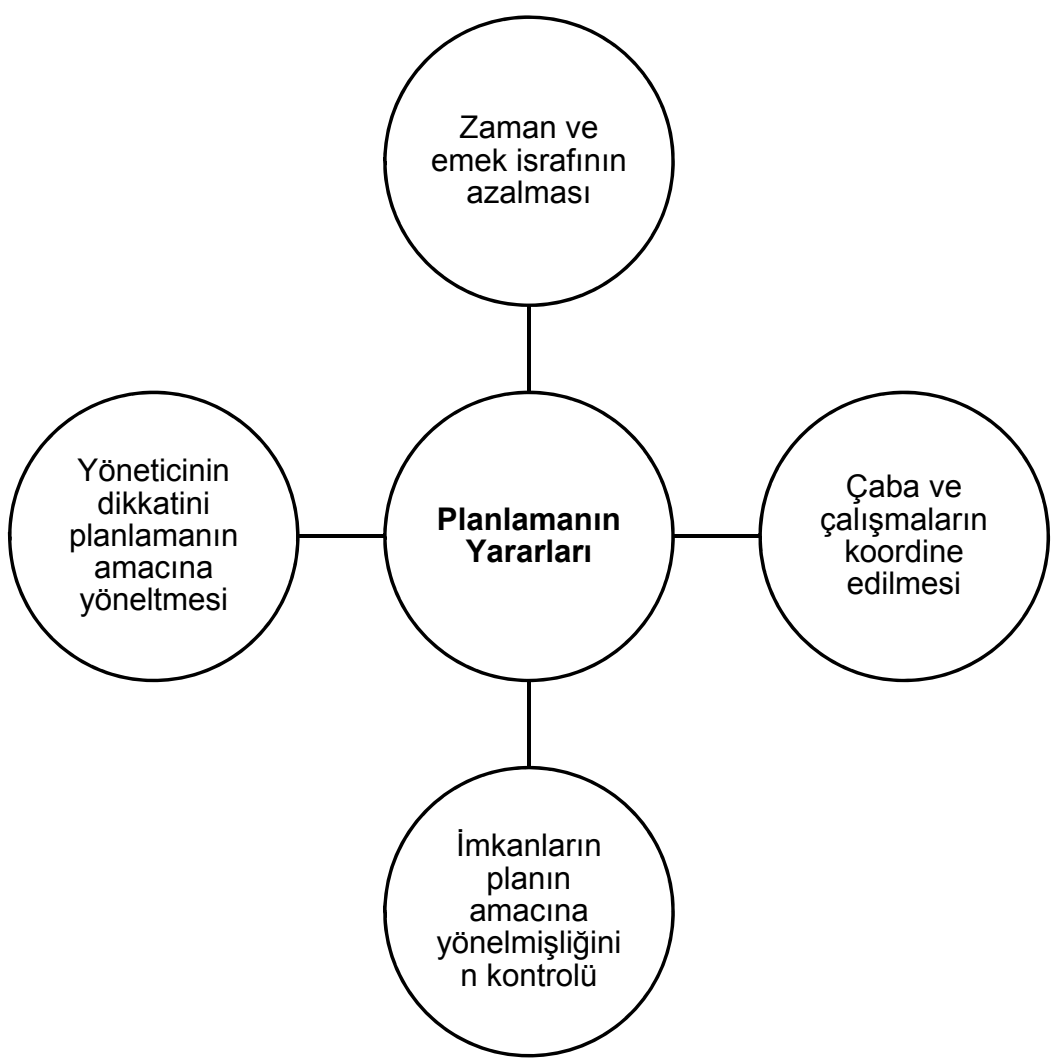

Şekil 1: Planlamanın Yararları (Gültekin, 2007, s.62)

$\mathrm{Bu}$ makalede planlama ve planlama çalışmalarının temelini oluşturan proje kontrol kurgusunun oluşturulması ve bunun üzerine iş programının yapılandırılması konularında genel bir bakış açısı sunulmak istenmiştir. Önemli görülen hususlar ana hatlarıyla açıklanmaya çalışılacaktır. Esasında bu bakış açısı tüm projelerde benzer şekilde uygulanabilir. Ancak burada tanımlamaların ve örneklemelerin rafineri projesi özelinde verilmesi tercih edilmiştir. Bugüne kadar edinilen tecrübelerle bu tip projelerin planlama çalışmalarının altyapısının kurulması ve takip detayları hakkında önerilerde bulunulmuştur. 


\section{PLANLAMA NEDIR?}

Planlama en genel manada istenen hedeflere ulaşabilmek için yapılan sistemli hesap ve tasarımların bütünü olarak düşünülebilir (Özışık, 2003, s.43). Planlamanın uygarlıklar tarihi boyunca var olduğunu düşünmek yanlış olmayacaktır. Sümer, Maya ve Mısır uygarlıklarının ortaya koydukları eserlerde planlamanın izlerini hissetmek mümkündür. Bu uygarlıklardan günümüze gelen birçok eserin nasıl bir planlamayla ve hangi teknikle yapıldıkları hala araştırma konusudur (Özışık, 2003, s.44).

Teknolojinin hızla ilerlemesi ve mevcut tekniklerin sorunlara yanıt verememesi nedeniyle, modern proje yönetim teknikleri 20. yüzyılın başlarında yavaş yavaş ortaya çıkmaya başlamıştır. 1917 yılında Henry GANTT proje iş sıralamasını oluşturmada büyük kolaylıklar sağlayan ve modern proje yönetim tekniklerinden biri olan GANTT diyagramını geliştirmiştir (Kır, 2007, s. 41). GANTT diyagramları çubuk diyagramlı iş programları olarak da bilinirler. Projede gerçekleştirilecek faaliyetleri temsil eden çubuklar, yatay eksenin zamanı dikey eksenin ise faaliyetleri gösterildiği bir grafiğe, iş akışına ve faaliyet sürelerine uygun olarak yerleştirilirler (Şekil 2). Böylece projenin toplam süresi ve faaliyetlerinin sıralanışı görülmüş olur. Çubuk diyagramlar ile projelerin zaman ve kaynak intiyaçları görülebilir ancak faaliyetleri arasındaki ilişkiler görülemezler (Özışık, 2003, s.80).

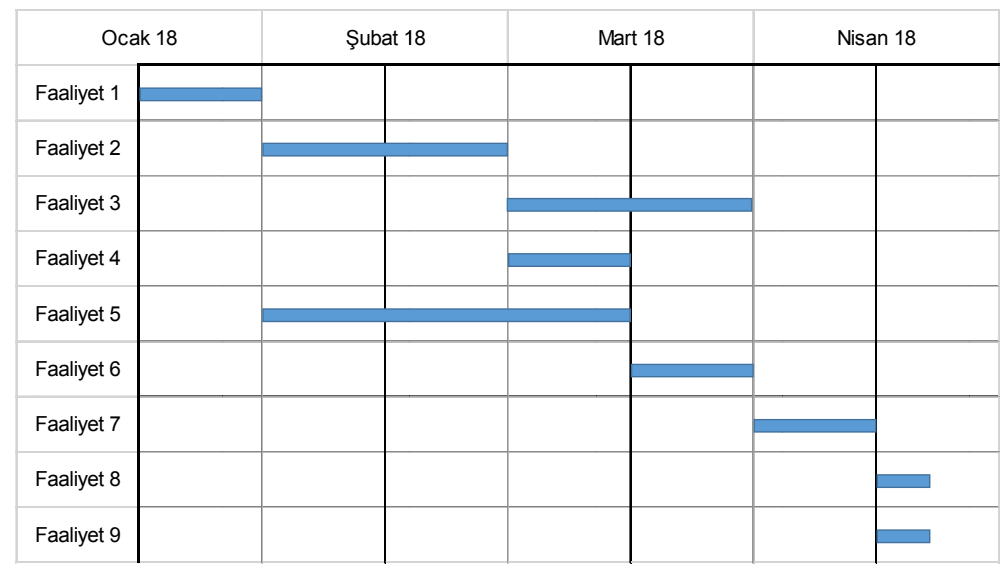

Şekil 2: GANTT Şeması

İkinci Dünya savaşından sonra firmalar, azalan işgücüne karşılık işlerin daha fazla karmaşıklığı karşısında daha pratik teknik arayışlarına girmişlerdir. Bu doğrultuda, GANTT diyagramının daha gelişmiş şekli olan CPM ve PERT diyagramları (Şekil 3), 1956-1958 yıllarında geliştirilmiştir (Coşkun, Ekmekçi, 2012, s.40).

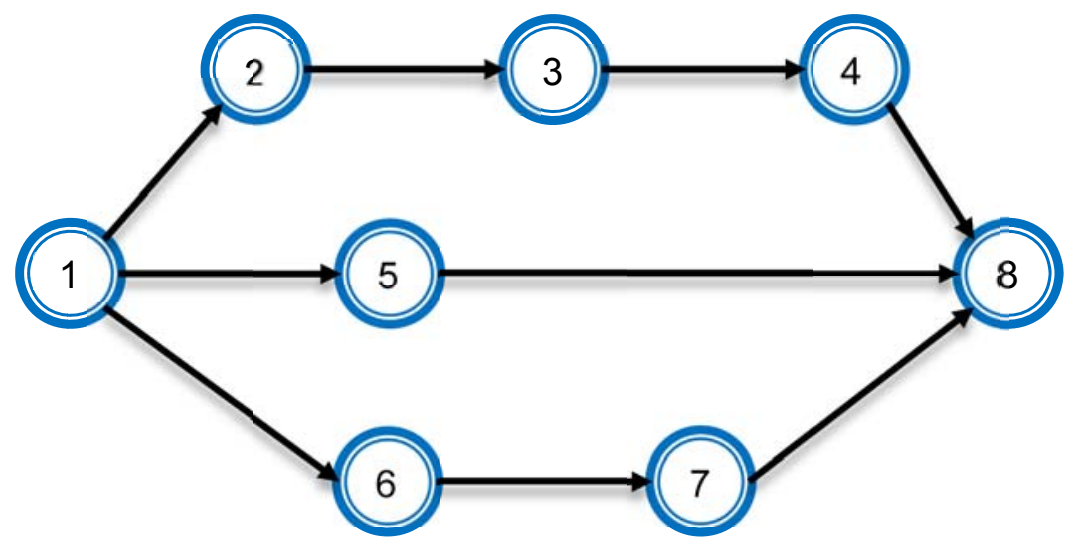


Rafineri Projelerinde Planlamanın Önemi ve Başarılı Bir Planlama İçin Öneriler

Importance of Planning in Refinery Projects and Recommendations for Successful Planning

\section{Sekil 3: CPM \& PERT Ağ Diyagramı}

CPM, E.I. du Pont de Nemours firması tarafından inşaat projelerine bir uygulama olarak geliştirilmiştir ve daha sonra Mauchly firması tarafından geliştirilerek günümüze kadar gelmiştir (Coşkun, Ekmekçi, 2012, s.40). Kritik yol veya kritik yörünge yöntemi olarak da bilinir. CPM metodunun en belirgin yararları şunlardır;

a.) Faaliyet ağı içerdiği ilişkilerle beraber tasarlandığı için projenin herhangi bir faaliyetindeki aksamanın diğer faaliyetler üzerindeki etkileri görülebilir.

b.) Projenin süresini belirleyen faaliyet zincirlerinin oluşturduğu kritik yol veya yollar bulunur.

c.) Faaliyetlerin kritik hale gelmemeleri için ne kadar gecikmeye tahammül edilebileceğini gösteren zaman bollukları bulunur.

d.) Süre, kaynak ve parasal sınırlamalara göre projenin davranışı incelenebilir ki bu yolla planlama stratejisinin analizi ve kontrolü sağlanmış olur (Özışık, 2003, s.80).

PERT metodunda ise CPM'den farklı olarak faaliyet süreleri her faaliyet için üç değişik süre düşünülerek hesaplanan ortalama süre ile belirlenir. Bunlar iyimser süre, kötümser süre ve beklenen sürelerdir. PERT metoduyla çalışma yapabilmek için iyi bir veri tabanı gereklidir. Bu nedenle fazla kullanılmayan bir metottur (Özışık, 2003, s.100).

\section{RAFINERI PROJELERINDE PLANLAMA}

Orta veya büyük ölçekli rafineri tesisi projeleri inşaat, çelik, mekanik, elektrik, enstrümantasyon, izolasyon, boya gibi değişik disiplinlere ait işlerin bir arada yapıldığı projelerdir. Bu işlerin tasarım, satınalma ve yapım süreçlerine ait aktivitelerinin hem kendi süreçlerine hem de diğer süreçlere ait aktivitelerle bir ilişki ağı içerisinde ardışık ya da eşzamanlı yapıılığı düşünülürse rafineri projelerinin proje yönetimi açısından karmaşık projeler olduğunu söyleyebiliriz. Proje yöneticisi projenin başında hedefleri belirler, gerekli kaynakları tespit eder, projenin ilerlemesiyle beraber de konan hedeflerin ne ölçüde başarıldığını gözlemleyerek sapmalar söz konusu ise nerelerde hangi tedbirlerin alınması gerektiğine karar verir. Bu tip projenin başarılı olması için alınan birçok önemli kararın ve yapılan birçok değerlendirmenin yön göstericisi planlama çalışmaları ve bu çalışmaların çıktılarıdır.

\subsection{Planlama çalışmalarının başlangıcı}

Planlama çalışmalarına başlamadan önce kesinlikle proje hakkında genel bir bilgi sahibi olunmalıdır. Bunun için idare ile yapılan sözleşmenin incelenmesi önemle tavsiye edilir. Bu sayede projenin kapsamında neler yapılacağı, ünitelerin teslim süreleri, projede uyulması gereken kaynak kısıtlarının olup olmadığı gibi projenin planlamasına yön verecek bilgilere sahip olunacaktır. Temel tasarım aşamasında taslak yerleşim planı oluşturulmuş ise üzerinde çalışılarak projeye ait ünite, tesis, binaların yerleşimleri ve birbirleri ile bağlantıları incelenebilir. Ekipman listesi ekipman tip ve sayıları hakkında fikir sahibi olunmasını sağlayacaktır. Proses akış şemaları (PFD) incelendiğinde de tesisisin çalışma mantığı üzerinde bilgi sahibi olunabilir.

Detay tasarım ve satınalma süreçleri için oluşturulacak iş programları temel tasarım çalışmalarını takiben projenin başlarında detaylandırılabilir. Ancak yapım sürecine ait iş programının geliştirilebilmesi için detay tasarım çalışmalarının belli bir aşamaya kadar ilerlemesi gereklidir. Çünkü kaynakların düzgün bir şekilde artış ve azalışlarının 
sağlanarak verimli kullanılabilmesi, sürelerin doğru olarak belirlenebilmesi için projenin tümü üzerinden bir bakışa intiyaç olacaktır. Bunun için de projede yapılacak işlerin miktar bilgilerine ve büyük ölçüde nihai hale gelmiş tesis yerleşim planına ihtiyaç vardır.

\subsection{Projenin iş ayrışım yapısının oluşturulması (WBS)}

Projenin bütünü üzerinden kurgulanacak bir kontrol yapısı sadece proje hakkında genel bir bilgi verecektir. Oysa projeyi uygun alt parçalara ayırıp, bilgileri en alt parçalardan toplayarak yukarı doğru taşıyıp proje geneline ulaşmak hem veri akışının doğruluğunu hem de bu verilerin daha iyi yorumlanabilmesini sağlayacaktır. Bu sayede projede örneğin bir gerilik tespit edildiğinde söz konusu geriliğin hangi alan ya da alanlarda olduğu bilinecek ve böylece alınacak tedbirler doğru adreslere yönlendirilebilecektir. Bu kurguyu sağlayabilmek için proje kontrol altyapısının oluşturulmasına o projenin "Iş Ayrışım Yapısı"nın hazırlanması ile başlanır.

İş ayrışım yapısı bir projeyi oluşturan faaliyetlerin organize edilerek düzenlenebilmesi için bir çerçeve vazifesi görür (AACE 10S-90, 2017, s.122). Yukarıdan aşağı doğru kurgulanmış hiyerarşik bir yapıyla her bir düzeye bir alt düzeyden daha ayrıntılı bilgi akışı sağlayan sistematik bir tümevarım yaklaşımı sağlar.

İş programının çerçevesini oluşturacak iş ayrışım yapısı projenin "Coğrafi Ayrışım Yapısı" ile "Süreç Ayrışım Yapısı"nın bir matris mantığında çakıştırılması ile elde edilir (Şekil 4).

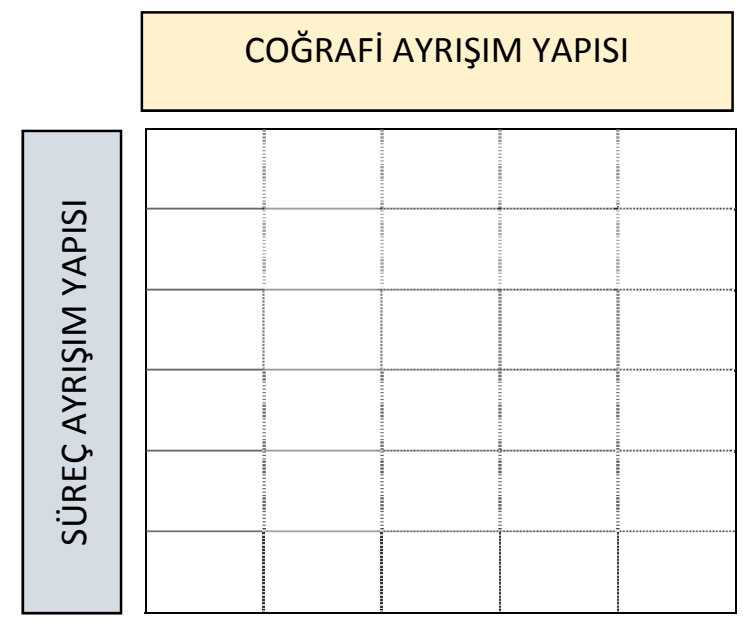

Şekil 4: İ̧̧ Ayrışım Yapısı Matrisinin Oluşumu

Coğrafi ayrışım projeyi oluşturan parçaların fiziki olarak ayrıştırımasıdır. Süreç ayrışımı ise projenin her bir sürecinin onu oluşturan alt disiplin, iş grubu ve nihayetinde aktivitelere ayrıştııılması olarak düşünülebilir. Bu iki ayrışımın çakıştııılmasıyla hangi bölgelerde hangi işlerin yapılacağını gösteren bir çerçeve elde edilir.

Şekil-5'de bir rafineri tesisinin şematik gösterimi verilmiştir. Buradan görüleceği üzere bu tesis dört ana kısımdan oluşmaktadır:

1. Proses Üniteleri (Process Units): Rafineri proseslerinin gerçekleştiği ünite ya da ünite gruplarıdır.

2. Yardımcı Tesisler (Utilities): Proses ünitelerinin çalışması için gerekli hava, buhar, demineralize su, elektrik gibi girdilerin elde edildiği ünitelerdir. 
Rafineri Projelerinde Planlamanın Önemi ve Başarılı Bir Planlama İçin Öneriler

Importance of Planning in Refinery Projects and Recommendations for Successful Planning

3. Tank Sahası (Tank Farm): Hammadde, yarı mamul ve mamullerin depolandığı tankların bulunduğu kısımdır.

4. Ünite ve tesisler arası bağlantıları sağlayan hatlar (Off-site): Yapılan yeni tesislerin birbirleri ile ya da mevcut diğer tesislerle bağlantılarını sağlayan iletim hatlarını içeren kısımlardır.

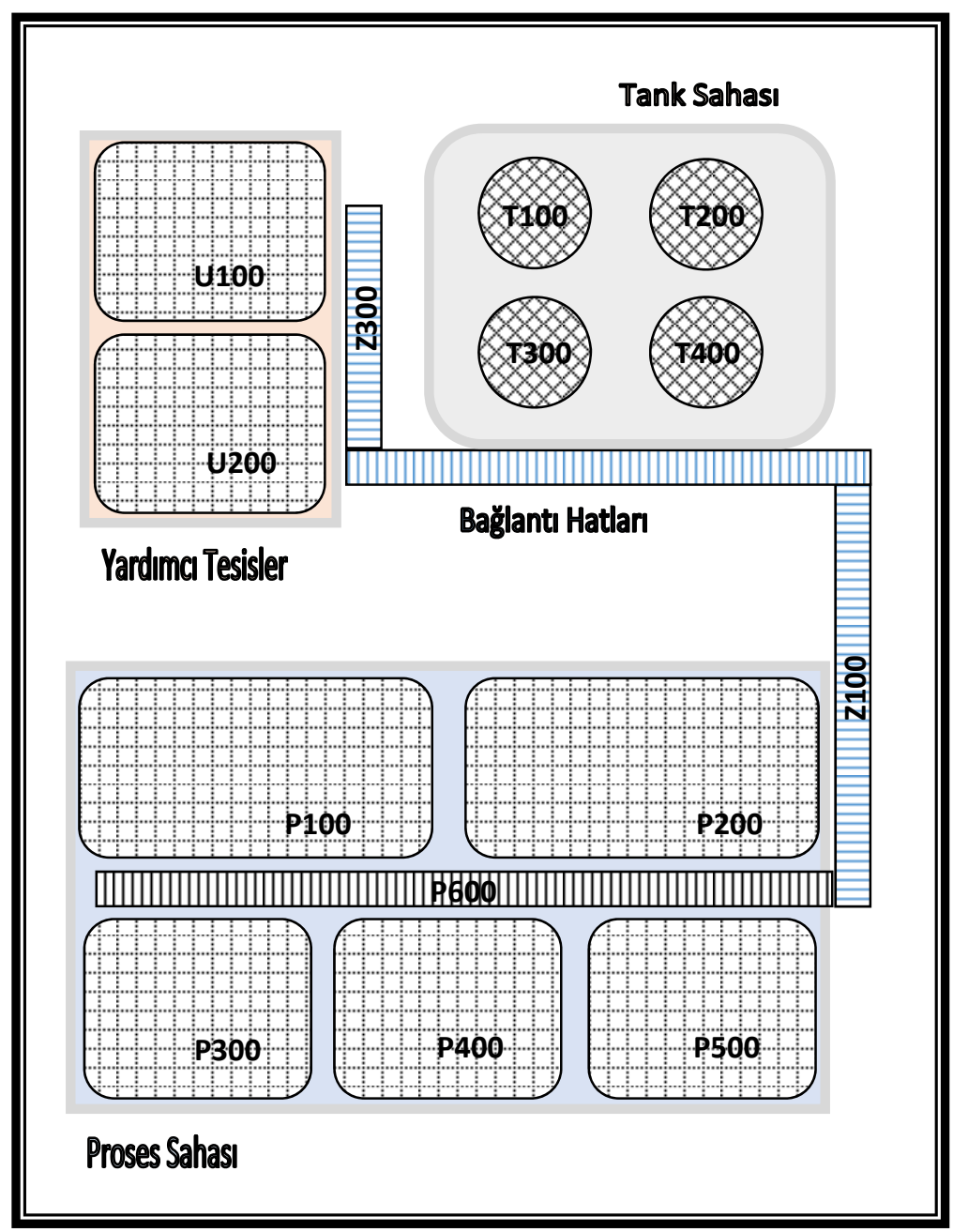

Şekil 5: Rafineri Tesisi Örnek Yerleşim Planı

Şekil-5'den yola çıkarak bu tesisin coğrafi ayrışım yapısı Tablo-1'deki gibi oluşturulabilir.

Süreç ayrışım yapısı ise tasarım, satınalma ve yapım süreçleri için ayrı ayrı kurgulanır. Bu ayrışım yapısında tanımlanan her bir seviye ilgili proje sürecinde yapılan işleri bizzat tarifler ve detaylandırır. 
Tablo 1: Örnek Coğrafi Ayrışım Yapısı

\begin{tabular}{|c|c|c|c|c|c|c|c|c|}
\hline $\begin{array}{l}\text { SEVIYE } \\
1\end{array}$ & \multicolumn{8}{|c|}{ PROJE GENELİ } \\
\hline $\begin{array}{l}\text { SEVIYE } \\
\quad 2\end{array}$ & P000 & $\begin{array}{l}\text { Proses } \\
\text { Sahası }\end{array}$ & U000 & $\begin{array}{l}\text { Yardımcı } \\
\text { Tesisler }\end{array}$ & T000 & Tank Sahası & Z000 & $\begin{array}{l}\text { Dış Saha } \\
\text { Bağlantı Hatları }\end{array}$ \\
\hline \multirow{6}{*}{$\begin{array}{c}\text { SEVIYE } \\
\mathbf{3}\end{array}$} & P100 & $\begin{array}{l}\text { Proses } \\
\text { Sahası-1 }\end{array}$ & U100 & $\begin{array}{l}\text { Yardımcı } \\
\text { Tesisler-1 }\end{array}$ & T100 & Tank-100 & Z100 & $\begin{array}{l}\text { Bağlantı Hatları } \\
\text { Modül-1 }\end{array}$ \\
\hline & P200 & $\begin{array}{l}\text { Proses } \\
\text { Sahası-2 }\end{array}$ & U200 & $\begin{array}{l}\text { Yardımcı } \\
\text { Tesisler-2 }\end{array}$ & T200 & Tank-200 & Z200 & $\begin{array}{l}\text { Bağlantı Hatları } \\
\text { Modül-2 }\end{array}$ \\
\hline & P300 & $\begin{array}{l}\text { Proses } \\
\text { Sahasi-3 }\end{array}$ & & & T300 & Tank-300 & Z300 & $\begin{array}{l}\text { Bağlantı Hatları } \\
\text { Modül-3 }\end{array}$ \\
\hline & P400 & $\begin{array}{l}\text { Proses } \\
\text { Sahasi-4 }\end{array}$ & & & T400 & Tank-400 & & \\
\hline & P500 & $\begin{array}{l}\text { Proses } \\
\text { Sahasi-5 }\end{array}$ & & & & & & \\
\hline & P600 & $\begin{array}{l}\text { Ana Boru } \\
\text { Köprüsü }\end{array}$ & & & & & & \\
\hline
\end{tabular}

Bir rafineri tesisi projesine ait süreçleri ve onları oluşturan alt disiplinleri şöyle sıralayabiliriz;

\section{Tasarım Süreci}

- İşçi Sağlığı ve Güvenliği \& Çevre

- Proje Tasarım ve Koordinasyon

- Proses Mühendisliği

- Betonarme ve Çelik Yapılar

- Borulama Mühendisliği

- Ekipmanlar

- Elektrik Sistemleri

- Enstrüman Sistemleri

2. Satınalma Süreci

$>$ Dinamik Ekipmanlar

> Statik Ekipmanlar

$>$ Paket Üniteler

$>$ Boru ve Aksesuarları

$>$ Elektrik Malzemeleri 


\section{$>$ Enstrüman Malzemeleri}

$>$ Diğer Malzemeler

\section{Yapım Süreci}

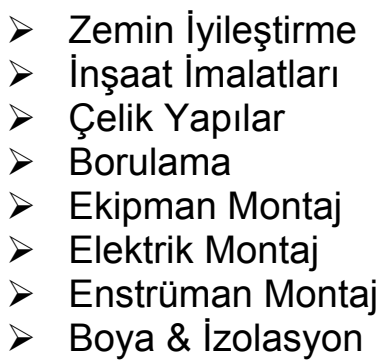

Aynı coğrafi ayrışım yapısında olduğu gibi süreç ayrışım yapısında da daha alt seviyelere inilebilir. Fikir vermesi açısından Tablo 2 ve Tablo 3'de örnekler verilmiştir.

Tablo 2: Tasarım için Örnek Süreç Ayrışım Yapısı

\begin{tabular}{|c|c|c|}
\hline Seviye-1 & Seviye-2 & Seviye-3 \\
\hline \multirow{8}{*}{$>$ Betonarme ve Çelik Yapılar } & \multirow{3}{*}{ - Genel Yapılar } & o Saha Betonları \\
\hline & & o Kablo Kanalları \\
\hline & & o Alt Yapılar \\
\hline & \multirow{3}{*}{ - Temeller } & o Ekipman Temelleri \\
\hline & & o Boru Köprüsü Temelleri \\
\hline & & o Çelik Yapı Temelleri \\
\hline & \multirow{2}{*}{ - Çelik Yapılar } & o Boru Köprüsü \\
\hline & & o Çelik Yapılar \\
\hline
\end{tabular}

Tablo 3: Satınalma için Örnek Süreç Ayrışım Yapısı

\begin{tabular}{|c|c|c|}
\hline Seviye-1 & Seviye-2 & Seviye-3 \\
\hline \multirow{7}{*}{$>$ Dinamik Ekipmanlar } & \multirow{4}{*}{ - Pompalar } & o OH2 Tip Pompalar \\
\hline & & o BB1 Tip Pompalar \\
\hline & & o BB2/BB3 Tip Pompalar \\
\hline & & o BB5 Tip Pompalar \\
\hline & \multirow{3}{*}{ - Kompresörler } & o Pistonlu Kompresörler \\
\hline & & o Santrifüj Kompresörler \\
\hline & & o Hava Üfleyici Fanlar \\
\hline
\end{tabular}

İş ayrışım yapıları projenin tasarım, satınalma ve yapım süreçleri için ayrı ayrı düşünülmeli ve sağlanmak istenen proje kontrol takip seviyesine göre oluşturulmalıdır. Belirlenen seviyelere göre iş programının iş ayrışım yapısı oluşturulduğunda iş programını oluşturacak aktivitelerin de seviyesi belirlenmiş olur. Aktiviteler seçilen süreç ayrışım seviyesinin bir alt seviyesinde olmalıdır. 
Aşağıda rafineri tesisi projelerinin her bir süreci için seçilebilecek ayrışım yapısı seviyeleri ile ilgili öneriler verilmiştir.

\subsection{Tasarım süreci için iş programının oluşturulması}

Tasarım süreci için proje ayrışım yapısı matrisi oluşturulurken coğrafi ayrışım yapısında üçüncü seviyenin seçilmesi uygun olacaktır. Süreç ayrışım yapısında ise ikinci seviye seçilmelidir. Bu durumda iş programını oluşturan aktiviteler ise süreç ayrışım seviyesi üçe karşı gelen aktivitelerden oluşacaktır (Tablo 4).

Tablo 4: Tasarım Süreci için Önerilen İş Ayrışım Yapısı Matrisi

\begin{tabular}{|c|c|c|}
\hline \multirow{2}{*}{\multicolumn{2}{|c|}{$X$}} & Coğrafi Ayrışım Yapısı \\
\hline & & Tablo-1 Seviye-3 \\
\hline 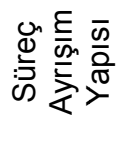 & 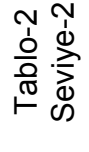 & Aktivite Seviyesi: Süreç Ayrışım Seviye-3 \\
\hline
\end{tabular}

Şekil-6'de bu yapıya uygun kurgulanmış basit bir örnek verilmiştir. P100 Proses Sahasının genel yapılarına ait betonarme ve çelik projelerinin iş programı oluşturulurken Tablo-1'de üçüncü seviye, Tablo-2'de ise ikinci seviye seçilmiştir. Benzer mantıkla Tablo-1'deki her bir seviye üç coğrafi alanı için Tablo-2'deki seviye ikiye ait işler iş programına aktarıldığında projenin tümü için tasarım süreci iş programı oluşmuş olur.

\begin{tabular}{|c|l|c|}
\hline Seviye & Aktivite Adı & TAKVIM \\
\hline C-1 & PROJE GENELI & \\
\hline C-2 & PROSES SAHASI & \\
\hline C-3 & P100 Proses Sahası-1 & \\
\hline S-1 & Betonarme ve Çelik Yapılar & \\
\hline S-2 & Genel Yapılar & \\
\hline S-3 & Saha Betonlarına ait Projelerin Hazırlanması & \\
\hline S-3 & Kablo Kanallarına ait Projelerin Hazırlanması & \\
\hline S-3 & Alt Yapılar ait Projelerin Hazırlanması & \\
\hline
\end{tabular}

Şekil 6: Tasarım Süreci için Örnek İş Programı

\subsection{Satınalma süreci için iş programının oluşturulması}

Satınalmalar tüm proje için ekipman paketleri bazında yapıldığı için proje ayrışım yapısı matrisi oluşturulurken proje geneli yani coğrafi ayrışım yapısı seviye-1 baz alınmalıdır. Süreç ayrışım yapısında ise üçüncü seviyeye inilmelidir. Bu durumda iş programını oluşturan aktiviteler ise süreç ayrışım seviyesi dörde karşı gelen aktivitelerden oluşacaktır (Tablo 5). 
Rafineri Projelerinde Planlamanın Önemi ve Başarılı Bir Planlama İçin Öneriler Importance of Planning in Refinery Projects and Recommendations for Successful Planning

Tablo 5: Satınalma Süreci için Önerilen İ̧̧ Ayrışım Yapısı Matrisi

\begin{tabular}{|c|c|c|}
\hline & & Coğrafi Ayrışım Yapısı \\
\hline & & Tablo-1 Seviye-1 \\
\hline 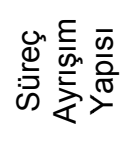 & 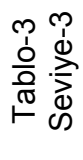 & Aktivite Seviyesi: Süreç Ayrışım Seviye-4 \\
\hline
\end{tabular}

Şekil-7'de proje geneli için $\mathrm{OH} 2$ tip pompaların satınalma iş programı oluşturulurken Tablo-1'de birinci seviye, Tablo-3'de ise üçüncü seviyeye seçilmiştir. Benzer mantıkla proje geneli için Tablo-3'deki her bir seviye üçe ait işler iş programına aktarıldığında projenin tümü için satınalma süreci iş programı oluşmuş olur.

\begin{tabular}{|c|l|l|}
\hline Seviye & Aktivite Adı & TAKVIM \\
\hline C-1 & PROJE GENELI & \\
\hline S-1 & Dinamik Ekipmanlar & \\
\hline S-2 & Pompalar & \\
\hline S-3 & OH2 Tip Pompalar & \\
\hline S-4 & $\begin{array}{l}\text { OH2 Tip Pompalar için Teknik Tekliflerin } \\
\text { Toplanması }\end{array}$ & \\
\hline S-4 & $\begin{array}{l}\text { OH2 Tip Pompalar için Teknik Tekliflerin } \\
\text { Değerlendirilmesi }\end{array}$ \\
\hline S-4 & $\begin{array}{l}\text { OH2 Tip Pompalar için Ticari Tekliflerin } \\
\text { Toplanması }\end{array}$ & \\
\hline S-4 & $\begin{array}{l}\text { OH2 Tip Pompalar için Ticari Tekliflerin } \\
\text { Değerlendirimesi }\end{array}$ & \\
\hline S-4 & $\begin{array}{l}\text { OH2 Tip Pompalar için Satınalma Siparişinin } \\
\text { Yayınlanması }\end{array}$ & \\
\hline
\end{tabular}

Şekil 7: Satınalma Süreci için Örnek İş Programı

\subsection{Yapım süreci iş programının oluşturulması}

Yapım süreci için proje ayrışım yapısı matrisi oluşturulurken coğrafi ayrışım yapısında üçüncü seviyenin seçilmesi uygun olacaktır. Süreç ayrışım yapısında ise yine üçüncü seviye seçilmelidir. Bu durumda iş programını oluşturan aktiviteler ise süreç ayrışım seviyesi dörde karşı gelen aktivitelerden oluşacaktır (Tablo 6).

Tablo 6: Yapım Süreci için Önerilen İş Ayrışım Yapısı Matrisi

\begin{tabular}{|c|c|c|}
\hline \multirow{2}{*}{\multicolumn{2}{|c|}{$X$}} & Coğrafi Ayrışım Yapısı \\
\hline & & Tablo-1 Seviye-3 \\
\hline : & $\stackrel{\substack{d \\
\grave{d}}}{\infty}$ & Aktivite Seviyesi: Süreç Ayrışım Seviye-4 \\
\hline
\end{tabular}


Şekil-8'de P100 Proses Sahasına ait ekipman temellerinin inşaat imalatları iş programı örneği verilirken hem coğrafi ayrışım yapısında hem de süreç ayrışım yapısında üçüncü seviyeye inildiği görülebilir.

\begin{tabular}{|c|l|l|}
\hline Seviye & Aktivite Adı & TAKVIM \\
\hline C-1 & PROJE GENELI & \\
\hline C-2 & PROSES SAHASI & \\
\hline C-3 & P100 Proses Sahası-1 & \\
\hline S-1 & Inşaat İmalatları & \\
\hline S-2 & Temeller & \\
\hline S-3 & Ekipman Temelleri & \\
\hline S-4 & G-101 Ekipman Temelinin Yapılması & \\
\hline S-4 & G-102 Ekipman Temelinin Yapılması & \\
\hline S-4 & G-103 Ekipman Temelinin YapıIması & \\
\hline
\end{tabular}

Şekil 8: Yapım Süreci için Örnek İş Programı

Bununla beraber yapım sürecinin borulama, elektrik, enstrüman ve boya \& izolasyon disiplinlerinde iş programı aktiviteleri için seviye dörde ulaşmak çok anlamlı olmayabilir. Örneğin bir sahadaki borulama işleri yukarıdaki örnekte olduğu gibi düşünüldüğünde her bir hat için bir aktivite tanımlanması gerekir. Bu durumda takibi çok anlamlı olmayan birbirine paralel başlangıç ve bitişi birbirine çok yakın birçok aktivite elde edilir. Oysa o sahadaki tüm hatlar için seviye üç olacak şekilde bir aktivite tanımlanır ve bu aktivitenin ilerlemesi de tüm hatların detaylarını içeren harici bir tabloda takip edilirse daha pratik ve doğru bir sistem kurulmuş olur. Özetle bu disiplinlerde aktivite seviyesi üçte tutulup seviye dört takibi için özel tablolar hazırlanmalı ve işin ilerlemesi bu tablolar ile takip edilmelidir.

\section{DEĞERLENDIRME VE SONUÇ}

$\mathrm{Bu}$ makalede anlatılan proje kontrol kurgusundan ve hazırlanan iş programından faydalanılarak birçok yeni çalışma üretilebilir. Bu yapı, işin fiziksel ilerlemesinin ölçülebileceği bir sistemin temeli olacağı gibi gerekli kaynak atamaları yapılması durumunda ekipman mobilizasyon planı, işgücü mobilizasyon planı, satınalma planı gibi çıktılara da ulaşmak mümkün olacaktır. Bununla beraber hazırlanan iş programının faydalı olabilmesi için şu hususları da göz ardı etmemek gerekir;

1. Proje kontrol kurgusu genel olarak planlamacının tasarladığı bir yapıdır. Ancak iş programı projedeki çalışanların ortak bir ürünü olmalıdır. İş programına ait aktivitelerin belirlenmesi, aralarındaki ilişkilerin tespiti, sürelerinin ve gerekli kaynakların hesaplanması gibi iş programının hazırlanması aşamalarında mutlaka aktivite sorumluları ile beraber çalışılmalıdır. Bu sayede program gerçekçi verilere dayanılarak oluşturulacağı gibi herkes tarafından sahiplenilip faydalanılan bir araç haline dönüşecektir.

2. Yeterli bilgi ve altyapıdan yoksun iş programlarında plandan sapmanın gerçekleşmesi kaçınılmazdır.

3. İş ayrışım yapısı ve dolayısıyla iş programını oluşturan aktivitelerin seviyeleri proje için gerekli takip seviyesi dikkate alınarak belirlenmelidir. Üst seviyede hazırlanan bir 
Rafineri Projelerinde Planlamanın Önemi ve Başarılı Bir Planlama İçin Öneriler

Importance of Planning in Refinery Projects and Recommendations for Successful Planning

iş programı yapılması istenen takip seviyesi için yüzeysel kalacak, gereğinden fazla detaylandırılmış iş programlarında ise iş gücü kaybı yaşanacaktır.

4. İş programlarında ilerlemelerin güncel tutulması vazgeçilmez bir şarttır. Aksi takdirde hedef ile karşılaştırma yapma imkânı kalmayacağından hazırlanan programdan da istenilen katkı alınamayacaktır.

Yeterli bilgi ve altyapı üzerine, proje çalışanlarının koordinasyonu ile hazırlanmış ve projenin yapı ve organizasyonuna uygun doğru takip seviyesinde kurgulanmış iş programlarının başarılı olma şansı yüksektir. Böylelikle projenin başta planlandığı gibi öngörülen hedefte, bütçede ve zamanda gerçekleşmesi sağlanabilir. Başarılı bir proje yönetimi ve planlamayla kısıtlı olan kaynakların etkin şekilde kullanılmasını ve kaliteli bir proje ortaya konulmasını sağlamak mümkündür.

\section{KAYNAKLAR}

AACE International, Cost Engineering Terminology, Recommended Practice No. 10S90, USA 2017, s.122.

Coşkun, Onur \& Ekmekçi, İsmail, Bir Inşaat Projesinin Evreleri Ille Zaman ve Maliyet Analizinin Proje Yönetim Teknikleri Vasıtasıyla Incelenmesi, İstanbul Ticaret Üniversitesi Fen Bilimleri Dergisi Sayı:20, İstanbul 2012, ss.39-53.

Çimen, Selahattin, Projelerde Başarıyı Belirleyen Faktörler ve Kamu Kuruluşlarında Bu Faktörlere Yaklaşımın Belirlenmesi, DPT Yayın No:2347-YSPKGM:575, Mayıs 1994, s.4.

Douglas, Edward E., Project Planning - Then Scheduling, 2004 ASCE International Transactions, USA 2004, PS.07, ss.1-5.

Gültekin, A. Tanju, Proje Yönetimi, Palme Yayıncılık, Ankara 2007, s.62.

Kır, Ertürk, Yazılım Sektöründe Proje Yönetimi, Yüksek Lisans Tezi, Kadir Has Üniversitesi Sosyal Bilimler Enstitüsü, İstanbul 2007, s.41.

Munns, Andrew \& Bjeirmi, Bassam, The Role of Project Management in Achieving Project Success, International Journal of Project Management Vol. 14, No. 2, UK 1996, ss.81-87.

Özışık, Ahmet G., Proje Yönetim Teknikleri, Birsen Yayınevi, İstanbul 2003, s.43,44,80,100.

Yalkı, İrem, Proje Yönetimi ve CPM-PERT Teknikleri Üzerine Bir Uygulama, Yüksek Lisans Tezi, Marmara Üniversitesi Sosyal Bilimler Enstitüsü, İstanbul 2009, s.3. 